\title{
PEMETAAN POTENSI LABORATORIUM KALIBRASI MASSA SEBAGAI PENGUATAN KETERTELUSURAN PENGUKURAN DI INDONESIA
}

\section{Mapping of The Potential Mass Calibration Laboratory for Strengthening Tracebility of Measurement in Indonesia}

\author{
Endi Hari Purwanto dan Suprapto
}

\author{
Pusat Riset dan Pengembangan Sumber Daya Manusia, Badan Standardisasi Nasional \\ Gedung I BPPT Lantai 12, Jalan M.H. Thamrin No. 8, Jakarta, Indonesia \\ e-mail: endi@bsn.go.id
}

Diterima: 11 Desember 2018, Direvisi: 12 Februari 2019, Disetujui: 18 Februari 2019

\begin{abstract}
Abstrak
Perkembangan ketertelusuran kalibrasi di Indonesia terpolarisasi pada wilayah tertentu, daerah JakartaTangerang dan sekitarnya. Informasi ketertelusuran kalibrasi yang ada, belum dapat menyediakan informasi yang memetakan pola ketertelusuran kalibrasi standar massa. Tujuan penelitian adalah memetakan potensi laboratorium kalibrasi massa melalui: 1) Peta potensi laboratorium kalibrasi untuk area baru (rintisan), 2) Peta potensi laboratorium Kalibrasi yang belum termanfaatkan dan 3) Peta potensi laboratorium kalibrasi yang belum optimal. Comparation Methode digunakan, dengan 3 pola yakni: pertama, membandingkan berdasarkan wilayah provinsi, kedua, membandingkan berdasarkan wilayah Provinsi yang sudah termanfaatkan untuk ketertelusuran pengukuran, ketiga, membandingkan ketersediaan standar massa terhadap pemanfaatannya menurut kelas massa. Hasilnya adalah wilayah Indonesia timur seperti: Nusa Tenggara Timur, Sulawesi Tengah, Sulawesi Tenggara, Sulawesi Utara, Maluku Utara, Maluku dan Papua Barat berpotensi sebagai daerah pengembangan rintisan laboratorium kalibrasi ketertelusuran, kemudian wilayah/kota berpotensi namun belum optimal meliputi: Sumatra Barat, Kepulauan Riau dan Sumatra Selatan, kemudian Yogyakarta, Kalimantan Tengah, dan Sulawesi Selatan. Wilayah dengan rasio pemanfaatan baik meliputi: Jabar-Banten-Jakarta (3,22), adapun wilayah yang rasio pemanfaatannya belum baik meliputi: Medan $(0,125)$ dan Banjarbaru $(0,76)$. Adapun standar menurut kelas massa yang rasio pemanfaatannya baik meliputi: E1 yaitu Jawa Barat-Banten-Jakarta $(3,22)$, kelas E2 yaitu Jabar-Tangerang-Banten-Cilegon (1,6) dan Bontang (1), kelas F1 yaitu Pekanbaru (3), Bandung-Bekasi-Bogor $(1,614)$ dan Bontang $(1,5)$ dan seteruanya sampai kelas M3. Disarankan penguatan ketersediaan laboratorium kalibrasi dengan CMC terbaik, sebaran laboratorium kalibrasi yang merata, meningkatkan kepercayaan masyarakat terhadap ketertelusuran pengukuran. BSN dapat membuka sejumlah unit pelayanan teknis SNSU di daerah untuk perluasan layanan akreditasi laboratorium kalibrasi yang ujungnya berdampak pada peningkatan kemudahan laboratorium kalibrasi daerah untuk melaksanakan ketertelusuran pengukuran.
\end{abstract}

Kata kunci: ketertelusuran, laboratorium kalibrasi, pemetaan, pemerataan layanan, rasio manfaat

\section{Abstract}

The development of calibration traceability in Indonesia is polarized in certain regions, the Jakarta-Tangerang region and its surroundings. Existing information on calibration traceability has not been able to provide information that maps the mass calibration tracing pattern. The research objective is to map the potential of mass Calibration through: 1) Map of potential Calibration Laboratories for new areas (stub), 2) Maps of potential Calibration Laboratories that have not been utilized and 3) Potential maps of Calibration Laboratories that have not been optimal. The Comparative Method is used, with 3 patterns, namely: first, comparing based on the Province, Second, comparing based on the Province which has been utilized for search search purposes. Third, comparing the standard of mass to its use according to the mass class. How does the East Indonesia region such as: NTT, Central Sulawesi, Southeast Sulawesi, North Sulawesi, North Maluku, Maluku and West Papua require the development of pilot tracking calibration areas, then the regions/cities that have not been optimally opened: West Sumatra, Riau Islands and South Sumatra, then Yogyakarta, Central Kalimantan, and South Sulawesi. Regions with good usage ratios: West Java-Banten-Jakarta (3.22), as for regions where the ratio of use has not been included: Medan (0.125) and Banjarbaru (0.76). For E1 class, namely West Java-Banten-Jakarta (3.22), E2 class namely West Java-Tangerang-Banten-Cilegon (1.6) and Bontang (1), F1 class namely Pekanbaru (3), Bandung-Bekasi-Bogor (1,614) and Bontang $(1,5)$ and as far as the M3 class. As much as equal Calibration Laboratories, increase public trust in measurement traceability. BSN can renew the SNSU technical service unit in the region to obtain calibration laboratory accreditation services whose ends improve on increasing regional calibration laboratory comfort to improve measurement traceability.

Keyword: benefit ratio, laboratory calibration, mapping, service equity, traceability 


\section{PENDAHULUAN}

Saat ini di Indonesia belum ada informasi yang memetakan potensi laboratorium kalibrasi ditinjau sebagai penguatan ketertelusuran pengukuran sehingga konsumen sulit mendapatkan informasi mengenai keberadaan laboratorium kalibrasi yang terakreditasi. Fenomena lain adalah konsumen yang cenderung melakukan kalibrasi alat ukur massa kepada Puslit Metrologi LIPI (standar primer) secara langsung padahal secara prinsip ketertelusuran dapat dikalibrasi di laboratorium kalibrasi yang memiliki kelas standar massa yang cukup 1 kelas lebih tinggi saja. Permasalahannya adalah belum adanya informasi yang memetakan kompetensi Laboratorium kalibrasi untuk standar sekunder satuan turunan saat ini ditinjau dari sisi tingkat ketidakpastian yang dimiliki, lingkup kalibrasi, jumlah konsumen yang dapat dilayani (kapasitas layanan), status kepemilikan baik pemerintah maupun swasta (Badan Standardisasi Nasional, 2010), dan sebaran lokasi laboratorium.

Informasi pemetaan ini sangat penting karena dapat diketahui potensi kompetensi laboratorium dalam mengkalibrasi alat uji untuk standar satuan turunan ditinjau dari sisi: 1) ketertelusuran laboratorium rujukan, 2) ketertelusuran kelas standar besaran (massa). Dengan demikian konsumen dapat menentukan pilihan untuk proses kalibrasi yang diperlukan secara mudah dan efisien namun tetap mampu telusur dengan baik. Kondisi tersebut mendorong diperlukan upaya memetakan potensi laboratorium kalibrasi di Indonesia dalam rangka penguatan ketertelusuran pengukuran di Indonesia. Tujuan penelitian ini adalah membuat: 1) Peta Potensi pengembangan wilayah "rintisan" per Provinsi, 2) Peta Potensi Pengembangan Laboratorium Kalibrasi tersedia di wilayah Provinsi yang sama sekali "belum termanfaatkan" sebagai ketertelusuran dan 3) Peta potensi "optimalisasi" Laboratorium kalibrasi ketertelusuran yang ada namun belum optimal termanfaatkan (per standar kelas massa).

\section{TINJAUAN PUSTAKA}

\subsection{Pemetaan Laboratorium Kalibrasi Massa}

Kalibrasi bertujuan memberikan jaminan bahwa alat yang telah dikalibrasi memiliki sifat ukur yang tertelusur ke standar nasional atau internasional. Kalibrasi adalah kegiatan untuk menentukan kebenaran konvensional nilai penunjukkan alat ukur dan bahan ukur dengan cara membandingkan terhadap standar ukur yang mampu telusur (traceable) ke standar nasional untuk satuan ukuran dan/atau internasional. BSN yang melakukan akreditasi Laboratorium Kalibrasi di seluruh Indonesia, dengan beragam jenis laboratorim kalibrasi massa (swasta dan pemerintah), dengan beragam kualitas kinerja laboratorium (nilai BMC dan CMC), dengan beragam kapabilitas mengkalibrasi dan beragam kelas standar massa yang dimiliki perlu menyediakan informasi kepada masyarakat mengenai laboratorium kalibrasi massa. Informasi yang disediakan harus dapat mengakomodasi kebutuhan laboratorium kalibrasi dalam melaksanakan ketertelusuran pengukuran kalibrasi. Salah satunya adalah dengan melakukan pemetaan. Pemetaan telah digunakan untuk memetakan beberapa analit dalam biotissue tanpa label kimia tertentu (Song, 2019). Pemetaan adalah mendapatkan data dan informasi yang rinci terkait sebaran laboratorium kalibrasi massa dan rincian kelas massa yang dimiliki.

\subsection{Pentingnya Ketertelusuran Pengukuran Kalibrasi}

Kalibrasi mempunyai peran penting dalam transaksi ekonomi dan produksi. Nampak dalam gambar bahwa kegiatan kalibrasi yang merupakan kegiatan metrologi ilmiah mendukung dan mendorong laboratorium kalibrasi melakukan kegiatan kalibrasi untuk dirinya dan untuk kepentingan eksternal. Standarisasi pengukuran (kalibrasi) merupakan prioritas utama di laboratorium pengujian, tujuannya adalah untuk mencapai perbandingan hasil yang lebih baik yang diperoleh dengan menggunakan sistem analisis rutin (Panteghini, 2009).

Ketertelusuran menjadi hal yang penting karena integritas hasil penilaian kesesuaian harus mampu menunjukan nilai benar. Nilai benar harus dibuktikan dengan kualitas uji banding/profisiensi dan keterbandingan hasil kalibrasi terhadap nilai kalibrasi laboratorium lainnya yang lebih baik nilai CMC-nya (nilai CMC lebih kecil). Laboratorium kalibrasi yang mempunyai nilai CMC rendah lebih baik dibandingkan laboratorium dengan nilai $\mathrm{CMC}$ tinggi. CMC (Calibration and Measurement Capability) ialah suatu nilai ketidakpastian terkecil yang dapat dihasilkan dalam kondisi rutin, untuk artefak dalam kondisi terbaik yang ada di pasaran (Tistomo, 2014). Nilai CMC adalah nilai ketidakpastian yang diperluas yang meliputi ketidakpastian alat yang diukur/dikalibrasi, metode pengukuran/kalibrasi, rentang ukur, parameter yang dipersyaratkan, dan nilai ketidakpastian terkecil yang dapat dicapai oleh laboratorium kalibrasi (Tistomo, 2014).

Posisi kalibrasi terhadap laboratorium kalibrasi dan laboratorium penguji. Dalam penilaian kesesuaian, integritas hasil suatu penilaian kesesuaian tergantung pada 6 faktor yakni: 1) Sejauh mana kualitas lembaga sertifikasi produknya, 2) Sejauh mana kualitas laboratorium pengujinya, 3) Sejauh mana kualitas kalibrasi alat ukur laboratorium pengujinya, 4) Sejauh mana kualitas laboratorium kalibrasi yang 
mengkalibrasi alat ukur laboratorium pengujinya, 5) Sejauh mana tingkat ketertelusuran laboratorium kalibrasi di Indonesia kepada laboratorium kalibrasi yang berada di atasnya, 6) Sejauh mana posisi rating CMC pada laboratorium kalibrasi SNSU di Indonesia terhadap negara lain baik secara kawasan maupun multilateral yang menjamin rantai ketertelusuran ke sistem satuan internasional yang tidak terputus.

Secara teknis nilai CMC memiliki peran yang sangat penting dalam proses integritas hasil suatu penilaian kesesuaian. Dengan menggunakan rata-rata nilai CMC, kita dapat melihat suatu gambaran kapabilitas dan kinerja laboratorium kalibrasi di Indonesia. Ada beberapa hal yang mempengaruhi nilai CMC untuk standar massa yaitu: 1) Ketidakpastian baku kalibrasi anak timbangan standar, 2) Ketidakpastian baku karena daya ulang pembacaan timbangan, 3) Ketidakpastian baku karena keterbatasan resolusi timbangan dan 4) Ketidakpastian baku karena pengaruh buoyancy udara (KAN, 2016).

\section{METODE PENELITIAN}

Penelitian ini dilaksanakan dengan menggunakan metode survei dan wawancara responden stakeholder yang meliputi 4 tahap yaitu: 1) survei laboratorium kalibrasi, 2) Studi literatur dan 3) wawancara laboratorium kalibrasi melalui FGD. Secara lengkap desain metode penelitian tersaji dalam Tabel 1.

Tabel 1 Desain metode penelitian.

\begin{tabular}{|c|c|c|c|c|c|c|c|}
\hline $\begin{array}{l}\text { Output } \\
\text { Penelitian }\end{array}$ & Keluaran & $\begin{array}{l}\text { Jenis } \\
\text { Data }\end{array}$ & $\begin{array}{l}\text { Sampling } \\
\text { Method }\end{array}$ & $\begin{array}{c}\text { Metode } \\
\text { Pengumpulan } \\
\text { Data }\end{array}$ & $\begin{array}{l}\text { Rumus } \\
\text { Olah Data }\end{array}$ & $\begin{array}{l}\text { Metode } \\
\text { Analisis }\end{array}$ & Kriteria \\
\hline 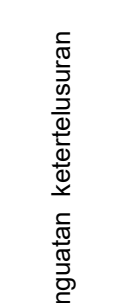 & $\begin{array}{l}\text { Peta potensi } \\
\text { pengembangan } \\
\text { wilayah rintisan } \\
\text { per provinsi }\end{array}$ & $\begin{array}{c}\text { sekunder } \\
\& \\
\text { primer }\end{array}$ & $\begin{array}{c}\text { Populasi* }) \\
(N=133)\end{array}$ & $\begin{array}{c}\text { Studi } \\
\text { literatur \& } \\
\text { survei } \\
\text { lapangan } \\
\text { sebagai } \\
\text { validasi }\end{array}$ & $\begin{array}{c}\text { Potensi } \\
\text { rintisan= } B-A \\
\star * * *)\end{array}$ & $\begin{array}{c}\text { analisis } \\
\text { kesenjangan } \\
\text { polarisasi }\end{array}$ & $\begin{array}{l}\text { potensi } \\
\text { pengembangan } \\
\text { = wilayah } \\
\text { provinsi di } \\
\text { Indonesia yang } \\
\text { sama sekali } \\
\text { belum terdapat } \\
\text { laboratorium } \\
\text { kalibrasi skema } \\
\text { KAN }\end{array}$ \\
\hline 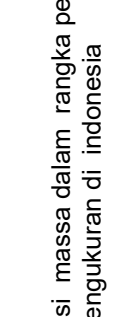 & $\begin{array}{l}\text { peta potensi } \\
\text { pengembangan } \\
\text { laboratorium } \\
\text { kalibrasi } \\
\text { tersedia di } \\
\text { wilayah provinsi } \\
\text { yang sama } \\
\text { sekali belum } \\
\text { termanfaatkan } \\
\text { sebagai } \\
\text { ketertelusuran }\end{array}$ & $\begin{array}{l}\text { Sekunder } \\
\& \\
\text { Primer }\end{array}$ & $\begin{array}{l}\text { Populasi } \\
(\mathrm{N}=133)\end{array}$ & $\begin{array}{c}\text { Studi } \\
\text { literatur \& } \\
\text { survei } \\
\text { lapangan } \\
\text { sebagai } \\
\text { validasi }\end{array}$ & $\begin{array}{l}\text { Potensi belum } \\
\text { termanfaatkan } \\
\quad=\mathrm{C}-\mathrm{C}^{\prime}\end{array}$ & $\begin{array}{c}\text { Analisis } \\
\text { kesenjangan } \\
\text { polarisasi by } \\
\text { provinsi }\end{array}$ & $\begin{array}{l}\text { Potensi } \\
\text { pengembangan } \\
=\text { laboratorium } \\
\text { kalibrasi } \\
\text { tersedia namun } \\
\text { sama sekali } \\
\text { belum } \\
\text { termanfaatkan } \\
\text { sebagai } \\
\text { ketertelusuran }\end{array}$ \\
\hline 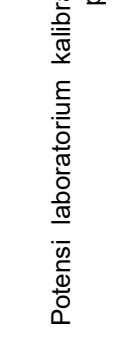 & $\begin{array}{l}\text { peta potensi } \\
\text { pengembangan } \\
\text { optimalisasi } \\
\text { laboratorium } \\
\text { kalibrasi } \\
\text { ketertelusuran } \\
\text { yang ada } \\
\text { namun belum } \\
\text { optimal } \\
\text { termanfaatkan } \\
\text { (per standar } \\
\text { kelas massa) }\end{array}$ & $\begin{array}{l}\text { Sekunder } \\
\text { dan } \\
\text { primer }\end{array}$ & $\begin{array}{l}\text { Populasi } \\
(\mathrm{N}=133)\end{array}$ & $\begin{array}{c}\text { Studi } \\
\text { literatur \& } \\
\text { survei } \\
\text { lapangan } \\
\text { sebagai } \\
\text { validasi }\end{array}$ & $\begin{array}{c}\text { Tingkat } \\
\text { optimalisasi }^{* *} \text { ) } \\
= \\
\text { Jumlah } \\
\text { ketersediaan } \\
\text { standar massa } \\
\text { / jumlah yang } \\
\text { merujuk pada } \\
\text { standar massa } \\
\text { tersebut. }\end{array}$ & $\begin{array}{c}\text { Analisis } \\
\text { kesenjangan } \\
\text { polarisasi by } \\
\text { kelas massa }\end{array}$ & $\begin{array}{l}\text { Jika**): } \\
\text { tingkat } \\
\text { optimalisasi } \geq 1 \\
=\text { termanfaatkan } \\
\text { optimal } \\
\text { tingkat } \\
\text { optimalisasi }<1 \\
=\text { belum } \\
\text { termanfaatkan } \\
\text { optimal }\end{array}$ \\
\hline
\end{tabular}

*) Penelitian ini menggunakan data populasi laboratorium kalibrasi yang diakreditasi KAN.

${ }^{* *}$ ) Jika nilai tingkat optimalisasi $\leqslant 1$, maka tingkat optimalisasi belum baik Jika nilai tingkat optimalisasi $\geq 1$ tingkat optimalisasi sudah baik

${ }^{* * *}$ ) Laboratorium yang tidak ada di suatu wilayah rintisan tidak berarti tidak membutuhkan akan tetapi ada potensi kebutuhan di wilayah tersebut tapi tidak terbaca oleh Badan Standardisasi Nasional, contohnya adalah Manado, Palu dan seterusnya.

Definisi keluaran:

1. Peta potensi pengembangan wilayah rintisan adalah diperoleh dari provinsi di wilayah Indonesia yang belum terdapat satu unit pun laboratorium kalibrasi berbasis skema KAN. Data polarisasi kepemilikan standar massa, digunakan sebagai data provinsi yang sudah dikembangkan Laboratorium Kalibrasinya.

2. Peta Potensi pengembangan laboratorium kalibrasi ketertelusuran adalah ketersediaan laboratorium kalibrasi ketertelusuran yang ada namun belum termanfaatkan sebagai ketertelusuran. 
3. Peta potensi pengembangan optimalisasi Laboratorium kalibrasi ketertelusuran yang ada namun belum optimal termanfaatkan.

\subsection{Alur Proses Pemetaan Potensi}

Penelitian ini dilakukan dengan mengikuti alur proses sebagaimana Gambar 2. Penelitian pemetaan ini bertujuan untuk: 1) memetakan laboratorium kalibrasi yang memiliki standar massa di Indonesia berdasarkan wilayah pulau/provinsi sehingga akan didapat peta wilayah provinsi mana saja yang belum dikembangkan di Indonesia. Wilayah inilah yang disebut wilayah yang berpotensi untuk pengembangan. Kemudian, 2) memetakan laboratorium kalibrasi yang memiliki standar massa yang termanfaatkan dan yang belum sebagai sumber ketertelusuran sehingga akan diperoleh peta wilayah provinsi/kota mana saja yang belum termanfaatkan sebagai sumber ketertelusuran dan 3) memetakan wilayah mana yang laboratorium kalibrasinya belum termanfaatkan secara optimal. Nilai optimal yang dimaksud apabila rasio jumlah standar massa tersedia terhadap standar massa termanfaatkan.

\subsection{Jenis Responden}

Penelitian menggunakan responden penelitian yaitu lembaga/laboratorium Kalibrasi massa yang terakreditasi KAN yang jumlahnya 133 Laboratorium kalibrasi massa yang masih aktif terakdreditasi KAN 2017. Setiap responden penelitian tersebut menjawab sejumlah pertanyaan dalam intrumen penelitian yang dibuat dalam bentuk kuesioner yang diserahkan sepenuhnya kewenangan menjawab adalah pada responden. Responden yang dipilih adalah orang menjabat sebagai kepala/pimpinan atau perwakilan lainnya yang kompeten dari lembaga/instansi/perusahaan yang dipilih dan dianggap layak menjawab pertanyaan dalam kuesioner.

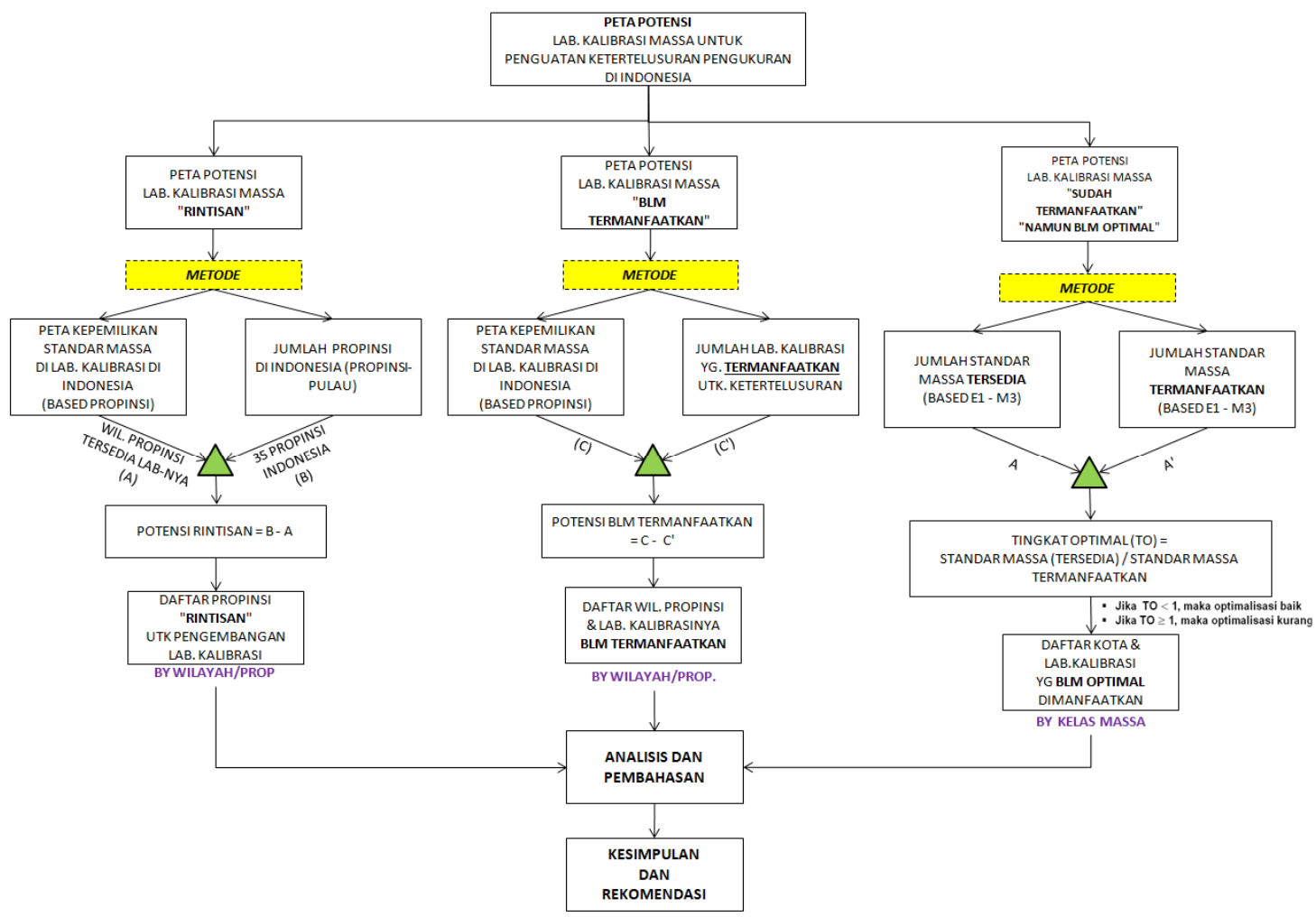

Gambar 1 Alur proses penelitian.

\subsection{Metode Pengambilan Data}

Data sekunder yang digunakan dalam penelitian ini yaitu dokumen pengajuan akreditasi laboratorium kalibrasi di seluruh Indonesia dengan ruang lingkup massa. Dalam dokumen terdapat informasi mengenai Laboratorium ketertelusuran dan kelas standar massa yang dimiliki. Selanjutnya informasi ditabulasi dalam matrik olah data untuk mendapatkan informasi yang dibutuhkan.

\subsection{Metode Penentuan Jumlah Data}

Dikarenakan akan menggambarkan kondisi di Indonesia secara keseluruhan maka digunakan data populasi dari responden berupa laboratorium kalibrasi yang diakreditasi KAN di Indonesia dengan ruang lingkup massa.

\subsection{Metode Analisis}

Analisis dilakukan dengan metode analisis kesenjangan polarisasi yaitu suatu metode yang 
dapat menjelaskan, menguraikan dan memetakan secara detil polarisasi yang terjadi dalam 3 hal yaitu 1) Polarisasi kepemilikan standar massa yang dimiliki laboratorium kalibrasi di Indonesia. Dengan metode ini dapat diketahui daerah mana yang masih belum terjamah yang dapat dikembangkan, 2) Kepemilikan standar massa di Indonesia namun belum dimanfaatkan. Dengan metode ini diketahui wilayah mana yang tersedia standar massa tersebut namun tidak menjadi sumber ketertelusuran dan 3) Kepemilikan standar massa di Indonesia yang sudah dimanfaatkan namun belum optimal.

\section{HASIL DAN PEMBAHASAN}

\subsection{Potensi Pengembangan di Wilayah Rintisan}

Dalam peta nampak ketersediaan laboratorium kalibrasi massa di Indonesia. Berdasarkan survei lapangan menunjukkan bahwa di Indonesia terdapat 112 standar E1, 324 standar E2,319 standar F1, 333 standar F2, 130 standar M1, 38 standar M2 dan standar massa M3 sebanyak 20 dari 133 laboratorium kalibrasi di Indonesia. Keseluruhannya tersebar di 46 kota di 18 provinsi, dengan dominasi kepemilikan standar berada di kota Jakarta yang mencapai 191 standar massa, Tangerang 160 standar massa, Bandung sebanyak 124 standar massa dan
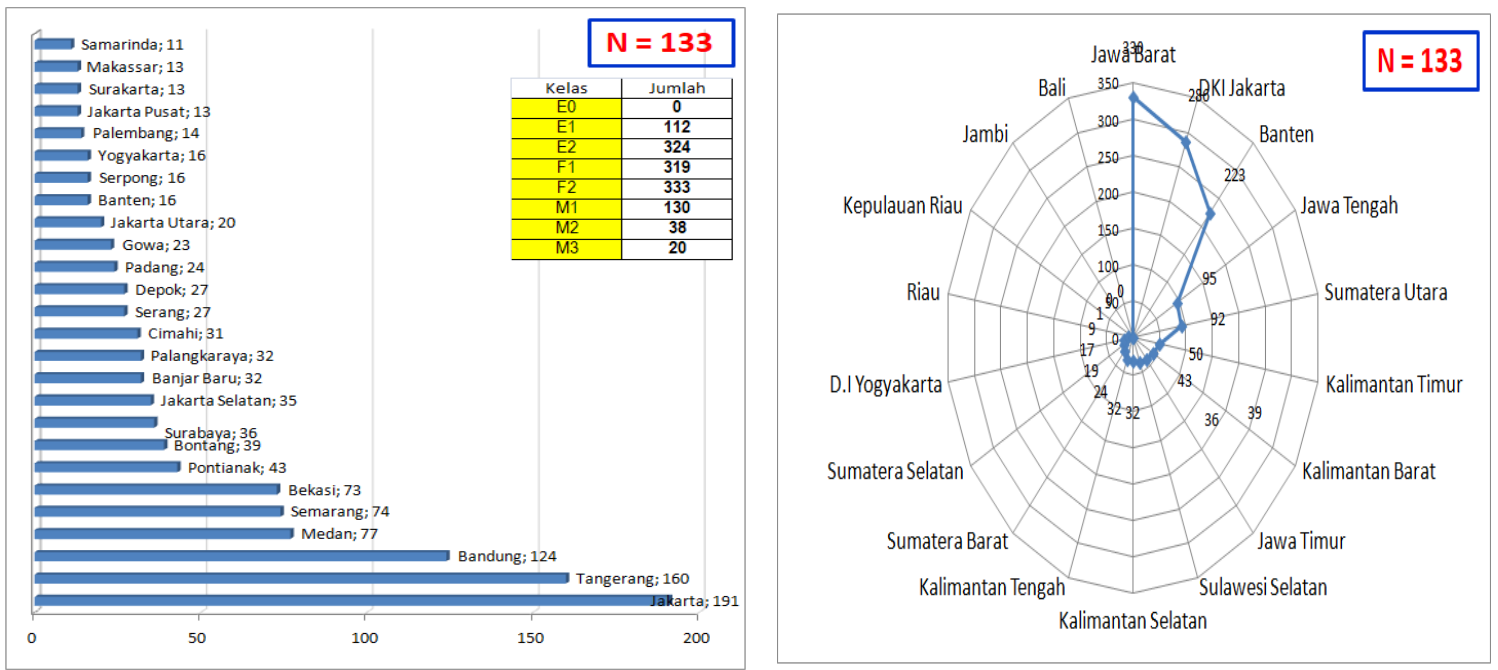

menyusul berikutnya adalah Medan (77 standar), Semarang (74) dan Bekasi (73). Secara lengkap tersaji dalam Gambar 3 dibawah ini.

Selanjutnya apabila dihitung berdasarkan provinsi maka terjadi polarisasi kepemilikan standar massa pada provinsi-provinsi sebagai berikut: Jawa Barat sebanyak 330 standar massa, DKI Jakarta sebanyak 286 standar massa, Banten sebanyak 223 standar massa, provinsi Jawa Tengah 95 standar massa, provinsi Sumatera Utara sebanyak 92 dan provinsi Kalimantan Timur sebanyak 50 standar massa.

Maka apabila dipetakan secara keseluruhan maka seluruh standar massa tersebut tersebar di wilayah nusantara dengan sebaran sebagaimana tersaji dalam peta. Dapat dijelaskan bahwa di Sumatera, standar massa tersebar di provinsi Kepulauan Riau (1), Sumatera Selatan (19), Sumatera Barat (24), Riau (9), Sumatera Utara (92). Adapun di pulau Jawa, standar massa tersebar di provinsi Yogyakarta (17), Jawa Timur (39), Jawa Tengah (95), Banten (223), DKI Jakarta (286) dan Jawa Barat (330). Sedangkan di Kalimantan, standar massa tersebar di provinsi Kalimantan Tengah (32), provinsi Kalimantan Selatan (32), Kalimantan Barat (43), Kalimantan Timur (50). Selanjutnya adalah di pulau Sulawesi, standar massa tersebar dimiliki di Sulawesi Selatan (36).

Gambar 2 Peta kepemilikan standar massa E0-M3 (kiri) dan polarisasi kepemilikan standar massa secara umum di Indonesia (kanan). 


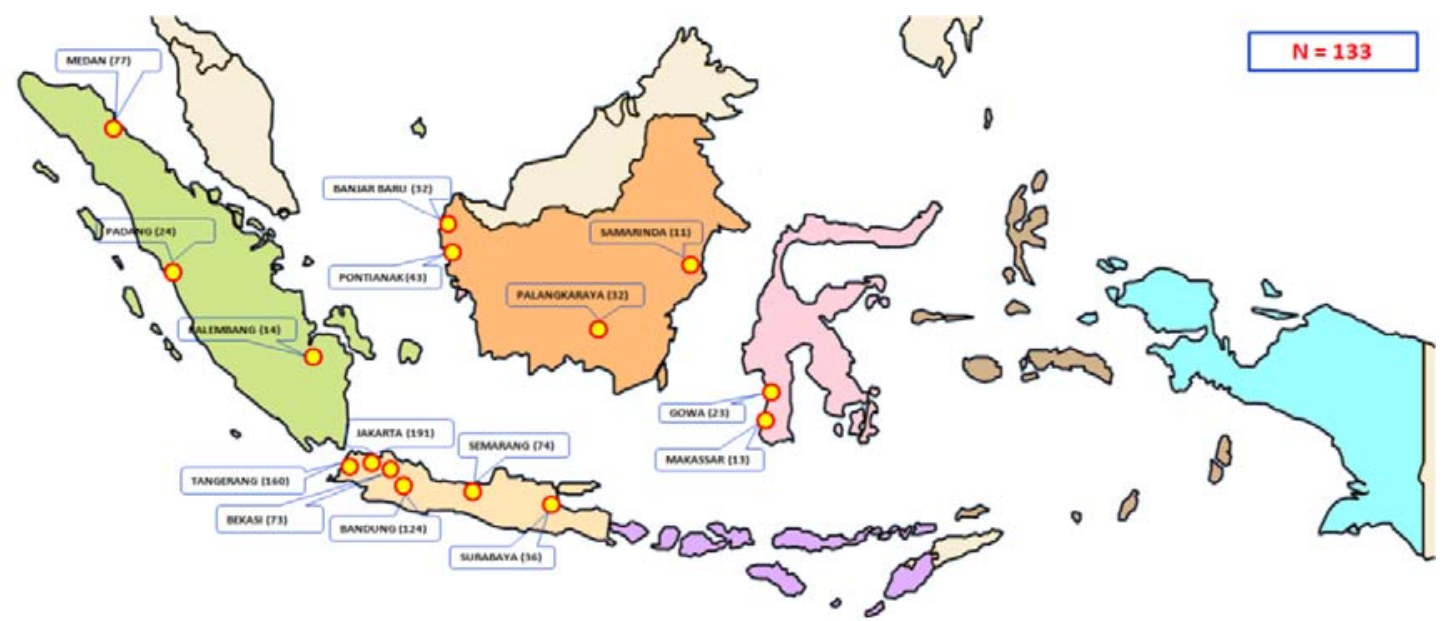

Gambar 3 Sebaran 16 wilayah provinsi yang tersedia laboratorium kalibrasi berbasis KAN (Provinsi/lbu kota).

Dalam Gambar 4 nampak terdapat 7 wilayah provinsi yang belum dikembangkan untuk laboratorium kalibrasi, yang sebagian besar dari laboratorium pengujian di wilayah tersebut sudah melakukan operasionalisasi proses ketertelusuran namun untuk kebutuhan internal Laboratorium penguji, sehingga banyak dari mereka yang belum bahkan tidak memerlukan akreditasi. Pengembangan di wilayah rintisan ini dilakukan untuk daerah, yaitu: Nusa Tenggara
Barat, Sulawesi Tenggara, Sulawesi Tengah, Sulawesi Utara, Maluku Utara, Maluku, Papua Barat dan Papua.

Pemerintah harus menangkap ini sebagai potensi yang dapat dikembangkan ke depan dengan mempertimbangkan jumlah market yang ada di wilayah tersebut dengan melakukan penelitian kebutuhan pasar kalibrasi massa di 7 wilayah tersebut.

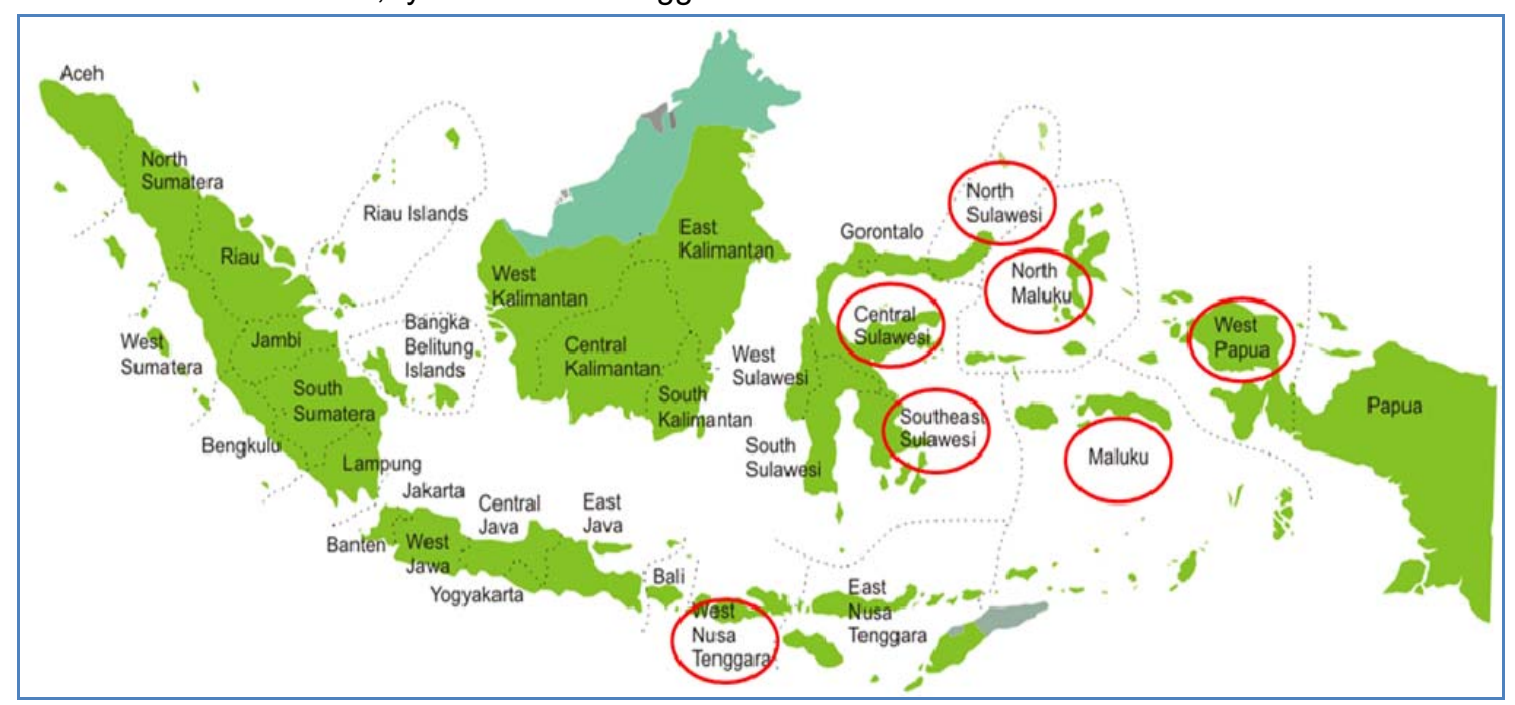

Gambar 4 Sebaran 7 wilayah provinsi yang belum ada laboratorium kalibrasi berbasis KAN (provinsi/lbu kota).

\subsection{Pengembangan di wilayah tersedia yang belum termanfaatkan}

Pengembangan difokuskan pada wilayah yang terdapat standar massanya namun belum menjadi sumber ketertelusuran (wilayah subtitusi). Padahal secara kemampuan telah tersedia untuk menerima layanan tersebut. Wilayah tersebut yaitu: Kepulauan Riau, Sumatera Barat, Yogyakarta, Kalimantan Tengah dan Kalimantan Timur. 


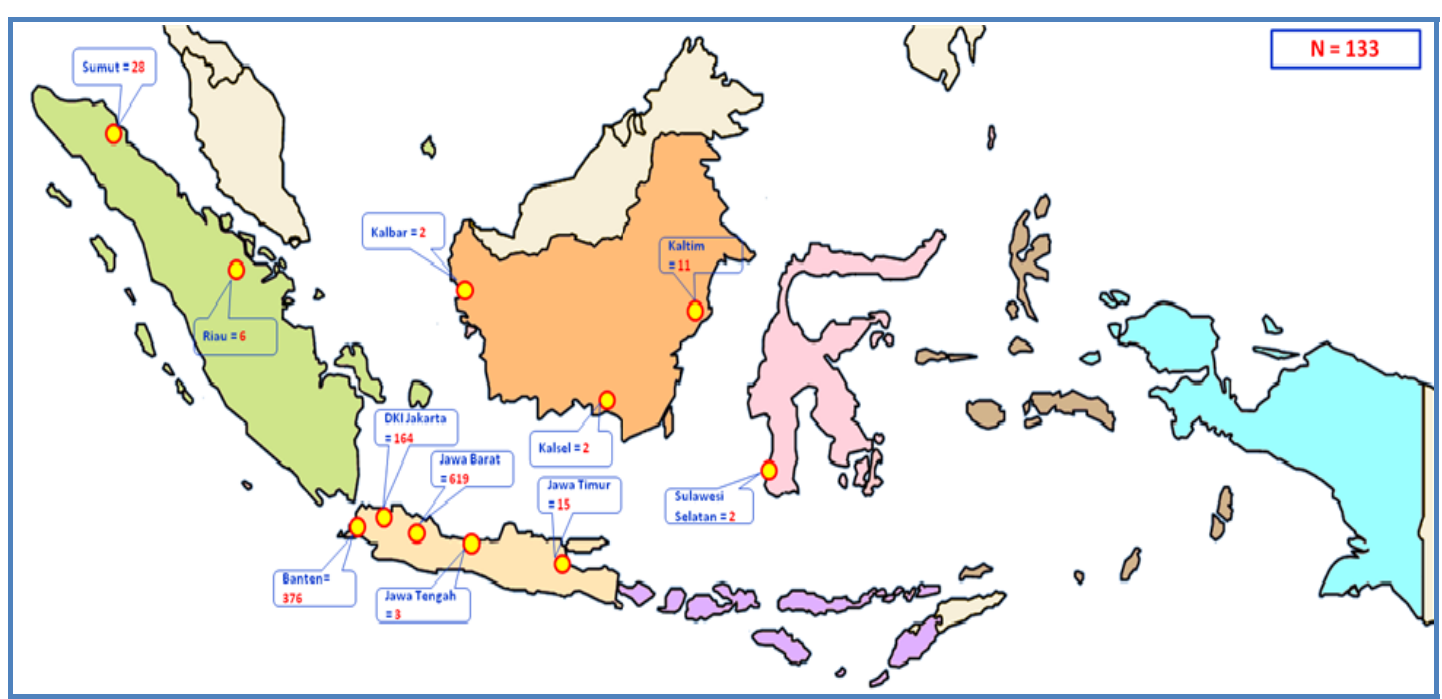

Gambar 5 Peta sebaran jumlah standar massa E0 s.d M3 yang digunakan sebagai "sumber ketertelusuran" menurut wilayah (Provinsi).

Sumber: Hasil pengolahan data peneliti (2017).

Gambar di atas memperlihatkan potensi yang dapat dikembangkan adalah titik wilayah yang ada dalam peta "kepemilikan" namun tidak ada dalam peta "sumber ketertelusuran" (Gambar 2). Artinya secara ketersediaan adalah ada namun tidak menjadi sumber rujukan ketertelusuran. Hal ini disebabkan oleh 4 aspek yaitu: 1) aspek tingkat kepercayaan, 2) aspek promosi yang belum gencar, 3) aspek ruang lingkup dan peruntukan laboratorium, 4) Kurang memadainya sistem informasi laboratorium kalibrasi di BSN yang memudahkan konsumen memilih laboratorium kalibrasinya dengan mudah.

\section{- Sumatera}

Berdasarkan hasil pengolahan data menunjukkan bahwa di Sumatera tersedia standar massa E0 sampai dengan M3 yang dimiliki Laboratorium Kalibrasi yang terakreditasi KAN adalah sebanyak 145 standar massa, namun secara umum teridentifikasi bahwa polarisasi terjadi di 2 provinsi saja, laboratorium kalibrasi digunakan sebagai rujukan ketertelusuran, yaitu: Sumatera Utara dengan Provinsi Riau. Artinya masih ada laboratorium kalibrasi di 3 wilayah Provinsi yang belum dimanfaatkan yaitu: Sumatera Barat, Kepulauan Riau dan Sumatera Selatan. Jumlah standar massa yang belum dimanfaatkan sebanyak 44 standar massa (E0-M3).

\section{- Jawa}

Hasil pengolahan data menunjukan bahwa di Pulau Jawa tersedia standar massa EO M3 yang dimiliki laboratorium kalibrasi yang terakreditasi KAN adalah sebanyak 998 standar massa, namun secara umum teridentifikasi bahwa polarisasi ketertelusuran terjadi di 6 provinsi untuk laboratorium kalibrasi digunakan sebagai rujukan ketertelusuran, yaitu: Provinsi Banten, Jakarta, Jawa Barat, Jawa Tengah dan Jawa Timur. Masih terdapat laboratorium-laboratorium kalibrasi di 1 wilayah provinsi yang belum dimanfaatkan yaitu provinsi Yogyakarta. Jumlah standar massa yang belum dimanfaatkan sebanyak 17 standar massa (E0-M3).

\section{- Kalimantan}

Fakta menunjukan bahwa di Pulau Kalimantan tersedia standar massa E0 - M3 yang dimiliki laboratorium kalibrasi yang terakreditasi KAN adalah sebanyak 157 standar massa, namun secara umum teridentifikasi bahwa polarisasi ketertelusuran terjadi di 3 provinsi untuk laboratorium kalibrasi digunakan sebagai rujukan ketertelusuran, yaitu: Kalimantan Barat (2), Kalimantan Timur (11) dan Kalimantan Selatan (2). Masih terdapat Laboratorium kalibrasi di 1 wilayah Provinsi yang belum dimanfaatkan yaitu Provinsi Kalimantan Tengah (32). Jumlah standar massa yang belum dimanfaatkan sebanyak 15 standar massa (E0-M3).

\section{- Sulawesi}

Di Pulau Sulawesi tersedia standar massa E0 - M3 yang dimiliki laboratorium kalibrasi yang terakreditasi KAN adalah sebanyak 36 standar massa, namun secara umum teridentifikasi bahwa polarisasi ketertelusuran terjadi di 1 Provinsi untuk Laboratorium kalibrasi digunakan sebagarujukan ketertelusuran, yaitu: Provinsi Sulawesi Selatan (2). Masih terdapat Laboratorium-Laboratorium 
kalibrasi yang belum dimanfaatkan. Mereka seluruhnya memiliki standar massa sebanyak 34 standar massa (E0-M3).
Secara lengkap terangkum dalam tabel di bawah ini.

Tabel 2 Wilayah kota/provinsi yang belum dimanfaatkan optimal.

\begin{tabular}{|c|c|c|c|c|}
\hline No & Pulau & $\begin{array}{l}\text { Kota/Provinsi } \\
\text { (Tersedia) }\end{array}$ & $\begin{array}{l}\text { Kota/Provinsi } \\
\text { (Dimanfaatkan) }\end{array}$ & $\begin{array}{c}\text { Kota/Provinsi } \\
\text { belum dimanfaatkan }\end{array}$ \\
\hline 1 & Sumatera & $\begin{array}{l}\text { Sumatera Utara, Sumbar, Riau, } \\
\text { Kep. Riau, Sumatera Selatan } \\
(145)\end{array}$ & $\begin{array}{l}\text { Sumatera Utara dan } \\
\text { Riau } \\
(34)\end{array}$ & $\begin{array}{l}\text { Sumbar, Kep. Riau, } \\
\text { Sumatera Selatan }\end{array}$ \\
\hline 2 & Jawa & $\begin{array}{l}\text { Banten, Jakarta, Jawa Barat, Jawa } \\
\text { Tengah, JawaTimur, Yogyakarta } \\
\text { (998) }\end{array}$ & $\begin{array}{l}\text { Banten, Jakarta, } \\
\text { Jawa Barat, Jawa } \\
\text { Tengah, JawaTimur }\end{array}$ & Yogyakarta \\
\hline 3 & Kalimantan & $\begin{array}{l}\text { Kalimantan Tengah, Kalimantan } \\
\text { Timur, Kalimantan selatan, } \\
\text { Kalimantan Tengah }\end{array}$ & $\begin{array}{l}\text { Kalimantan Tengah, } \\
\text { Kalimantan Timur, } \\
\text { Kalimantan selatan }\end{array}$ & Kalimantan Tengah \\
\hline 4 & Sulawesi & Sulawesi Selatan (36) & Sulawesi Selatan (2) & Sulawesi Selatan (34) \\
\hline
\end{tabular}

\subsection{Pengembangan optimalisasi Laboratorium Kalibrasi tersedia.}

Potensi optimalisasi yang difokuskan pada kelas standar massa yaitu E1, E2, F1, F2, M1, M2 dan M3. Potensi adalah selisih antara wilayah dalam peta "kepemilikan" terhadap wilayah dalam peta sumber "ketertelusuran" laboratorium kalibrasi. Potensi ini berfokus pada pemerataan pemanfaatan standar massa yang tersedia agar digunakan sebagai sumber ketertelusuran di Indonesia. Pengembangannya dapat dilakukan dengan perbaikan kalibrasi, pembukaan ruang lingkup baru di KAN, dan promosi yang lebih luas kepada klien (konsumen).

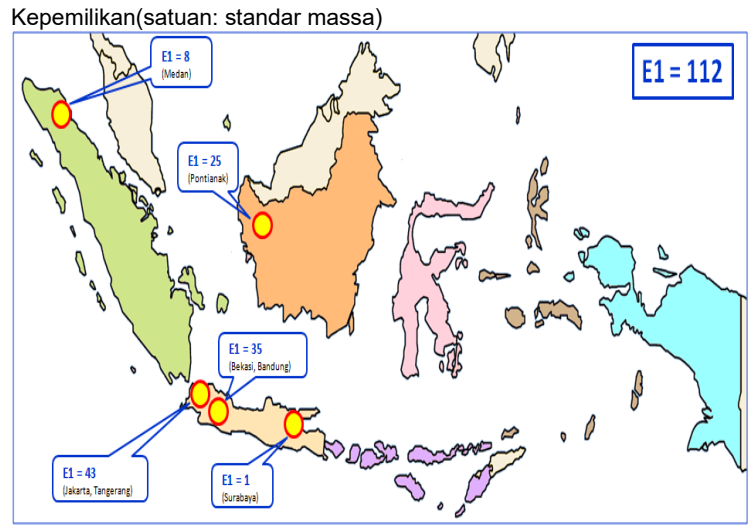

\section{a) Kelas E1}

Berdasarkan hasil pemetaan kepemilikan standar massa E1 yang dimiliki laboratorium kalibrasi, maka yang dominansi polarisasi ketertelusuran terjadi di Sumatera Utara, DKI Jakarta, Banten, Jawa Barat, Yogyakarta, Surabaya dan Pontianak. Peta di bawah ini menunjukkan bahwa standar massa E1 di Indonesia terdapat 112 kepemilikan standar massa yang terdapat di 12 laboratorium kalibrasi di beberapa titik polarisasi seperti yang disebutkan di atas.

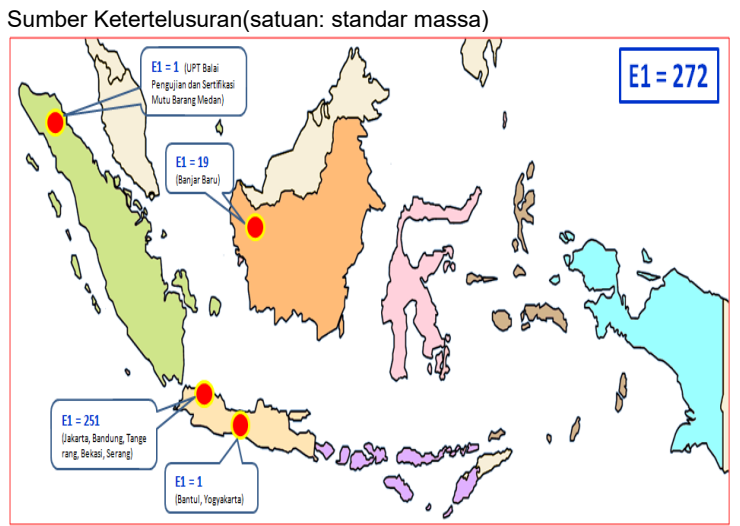

Gambar 6 Perbandingan standar massa E1 yang tersedia dengan standar massa yang termanfaatkan menurut wilayah.

Sumber: Hasil pengolahan data peneliti (2017).

Jawa. Berdasarkan hasil pengolahan data menunjukkan bahwa di pulau jawa tersedia standar massa E1 yang dimiliki laboratorium kalibrasi yang terakreditasi KAN adalah sebanyak 79 standar massa E1, yang terfokus hanya pada kota Bandung (1 standar), Bekasi (34 standar), Jakarta/Tangerang (43 standar) dan Surabaya (1 standar). Jumlah 79 standar massa tersebut yang terbesar berturut-turut yaitu: PT TUV Nord Indonesia Laboratory 
Division, Bekasi (33 standar), Puslit Metrologi LIPI (24 standar), BMD Laboratory (8 standar), PT.Kaliman dan PT. Mandiri Transforma Global (masing-masing 5 standar). Namun secara umum teridentifikasi bahwa polarisasi wilayah yang banyak digunakan sebagai standar ketertelusuran adalah Provinsi DKI Jakarta, Banten, Jawa Barat tepatnya kota Jakarta, Bandung, Tangerang, Bekasi dan Serang dengan jumlah 251 standar E1 dan provinsi Yogyakarta dengan jumlah 1 standar E1. Keberadaan laboratorium kalibrasi di pulau jawa sangat banyak dijadikan sumber ketertelusuran standar massa E1 oleh standar massa E2. Polarisasi ketertelusuran E1 untuk mengkalibrasi
E2 di pulau jawa tersebut secara umum didominasi oleh laboratorim yang terbanyak sampai yang tersedikit berturut-turut adalah sebagai berikut: 1) Puslit Metrologi ditelusur oleh sebanyak 96 standar E2, 2) Balai Standar Nasional Satuan Ukuran Direktorat Metrologi ditelusur oleh sebanyak 86 standar E2, 3) Balai Kalibrasi Direktorat Standardisasi dan Pengendalian Mutu Barang ditelusur oleh sebanyak 29 standar E2, dan 4) PT Almega Sejahtera ditelusur sebanyak 15 standar E2. Selengkapnya dapat dilihat dalam rangkuman sebagai berikut:

Tabel 3 Wilayah yang belum optimal dimanfaatkan (E1).

\begin{tabular}{llllll}
\hline \multirow{2}{*}{ No } & Pulau & $\begin{array}{l}\text { Standar Massa } \\
\text { (Tersedia) }\end{array}$ & $\begin{array}{l}\text { Standar } \\
\text { Massa } \\
\text { (Termanfaatkan) }\end{array}$ & $\begin{array}{l}\text { Rasio } \\
\text { Manfaat } \\
\text { Total }\end{array}$ & $\begin{array}{l}\text { Kota Belum Optimal } \\
\text { Dimanfaatkan }\end{array}$ \\
\hline 1 & Sumatera & Medan (8) & Medan (1) & 0,125 & Medan \\
\hline 2 & Jawa & $\begin{array}{l}\text { Jabar-Banten-Jakarta } \\
(78)\end{array}$ & $\begin{array}{l}\text { Jabar-Banten-Jakarta } \\
(251)\end{array}$ & 3,22 & OK \\
\cline { 3 - 6 } & Surabaya (1) & 0 & 0 & Surabaya \\
\cline { 2 - 6 } & Kalimantan & Pontianak (25) & Yogyakarta (1) & - & OK \\
\hline 3 & Kanjar Baru (19) & 0,76 & Pontianak \\
\hline
\end{tabular}

Sumber: Hasil pengolahan data peneliti (2017).

\section{b) Kelas E2}

Berdasarkan hasil pemetaan kepemilikan standar massa E2 yang dimiliki laboratorium kalibrasi, maka didominasi di provinsi: Medan, Pekanbaru, Palembang, Jakarta, Tangerang, Banten, Cilegon, Yogyakarta, Surakarta, Semarang, Pontianak, Palangkaraya, Samarinda, Bontang, Gowa dan Jatim. Peta di bawah ini menunjukkan bahwa standar massa E2 di Indonesia terdapat 324 kepemilikan standar massa yang terdapat di 65 laboratorium kalibrasi di beberapa titik polarisasi seperti yang disebutkan di atas.
Berturut-turut laboratorium kalibrasi dengan kepemilikan standar E2 terbanyak yaitu: 1) Balai Kalibrasi Direktorat Standardisasi dan Pengendalian Mutu Barang (LK 008) terdapat 33 standar, 2) PT Mandiri Transforma Global (LK 054) terdapat 33 standar, 3) Balai Pengujian dan Sertifikasi Mutu. Barang Dinas Perindustrian dan Perdagangan Provinsi Kalimantan Tengah (LK 204) terdapat 32 standar dan 4) Balai Standardisasi Metrologi Legal Regional III (LK 171) terdapat 28 standar E2.

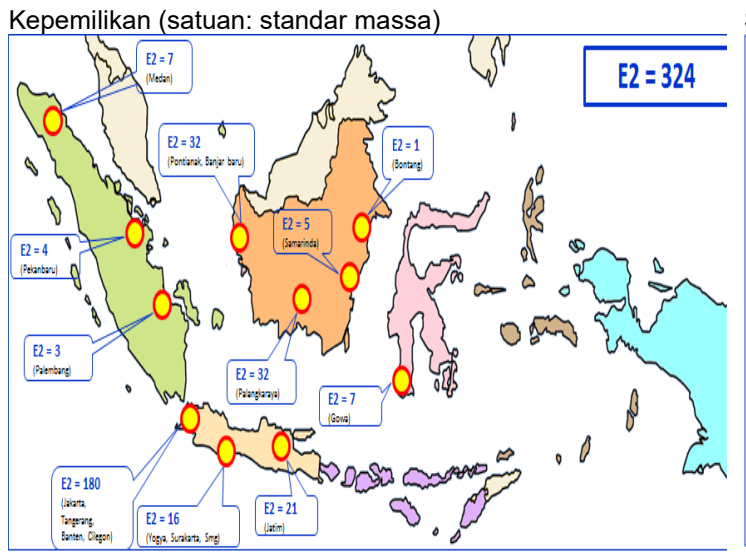

SumberKetertelusuran (satuan: standar massa)

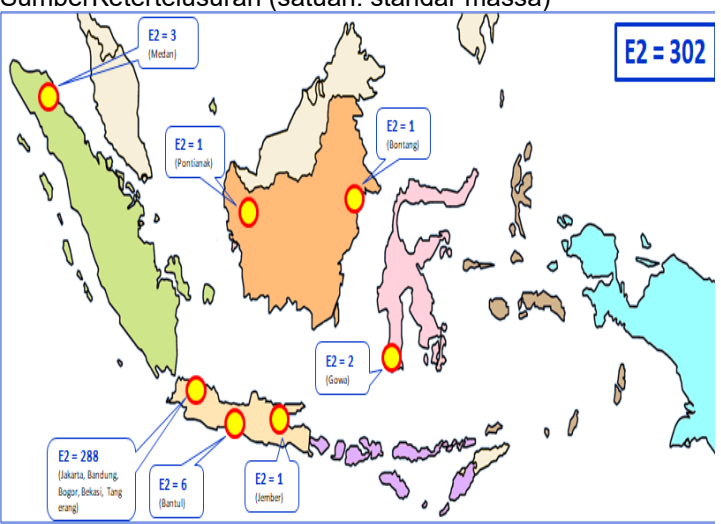

Gambar 7 Perbandingan standar massa E2 yang tersedia dengan standar massa yang termanfaatkan menurut wilayah.

Sumber: Hasil pengolahan data peneliti (2017). 
Sumatera. Berdasarkan hasil pengolahan data menunjukkan bahwa di pulau Sumatera tersedia standar massa E2 di laboratorium kalibrasi yang terakreditasi KAN adalah sebanyak 14 standar massa yang terfokus hanya pada kota Medan. Empat belas standar massa tersebut meliputi:

1) PT. Universal Technical Services (Medan) sebanyak 3 standar E2,

2) Balai Standardisasi Metrologi Legal Regional I (Medan) sebanyak 2 standar E2,

3) Balai Riset dan Standardisasi Industri Medan sebanyak 2 standar E2,

4) Departemen Laboratorium PT Pupuk Sriwidjaja (Palembang) sebanyak 4 standar 4 E2

5) UPT PSMB Prov. Riau sebanyak 2 standar.

Berdasarkan olah data menunjukkan bahwa yang melakukan kalibrasi standar ke E2 di wilayah Sumatera hanya 3 standar yaitu: 1) Balai Riset dan Standardisasi Industri Medan (2 standar) ke UPT Balai Pengujian dan Sertifikasi Mutu Barang Medan dan 2) Balai Standardisasi Metrologi Legal Regional I (1 standar) ke Balai Standardisasi Metrologi Legal Regional I Medan.
Diperlukan sosialisasi dan peningkatan ruang lingkup dan pendanaan pemeliharaan terhadap sejumlah Laboratorium di Sumatera, Kalimantan dan Sulawesi yang banyak melakukan kalibrasi ke Jawa. Terdapat 4 sebab mengapa terjadi polarisasi ketertelusuran di Jawa yaitu: 1) Banyak laboratorium kalibrasi di daerah tidak memiliki standar massa yang lengkap mulai dari satuan $\mathrm{mg}$, gram hingga kilogram, 2) Banyak juga laboratorium kalibrasi yang tidak semua standar massanya terkalibrasi secara rutin, 3) Akibat tidak terkalibrasi rutin maka tidak semua standar massa yang dimiliki tersebut mempunyai nilai ketidakpastian diperluas yang bagus (rendah), misal kelas E1 semua atau E2 semua untuk semua satuan. 4) Tersedia standar massa milik perusahaan di daerah namun fungsinya hanya untuk keperluan internal. Sebagai bukti adalah dari 5 laboratorium kalibrasi di Sumatera hanya 2 yang memiliki kelas E2 yaitu 1) PT. Pupuk Sriwijaya (internal), dan 2) Balai Standardisasi Metrologi Legal Regional I namun dengan kondisi tidak lengkap. Selengkapnya dapat dilihat dalam rangkuman sebagai berikut:

Tabel 4 Wilayah yang belum optimal dimanfaatkan (E2)

\begin{tabular}{|c|c|c|c|c|c|}
\hline No & Pulau & $\begin{array}{l}\text { Standar Massa } \\
\text { (Tersedia) }\end{array}$ & $\begin{array}{l}\text { Standar } \\
\text { Massa } \\
\text { (Termanfaatkan) }\end{array}$ & $\begin{array}{l}\text { Rasio } \\
\text { Manfaat } \\
\text { Total }\end{array}$ & $\begin{array}{l}\text { Kota Belum } \\
\text { Optimal } \\
\text { Dimanfaatkan }\end{array}$ \\
\hline \multirow[t]{3}{*}{1} & \multirow[t]{3}{*}{ Sumatera } & Medan (7) & Medan (3) & 0,425 & Medan \\
\hline & & Pekanbaru (4) & - & $\sim$ & Pekanbaru \\
\hline & & Palembang (3) & - & $\sim$ & Palembang \\
\hline \multirow[t]{3}{*}{2} & \multirow[t]{3}{*}{ Jawa } & $\begin{array}{l}\text { Jabar-Tangerang-Banten- } \\
\text { Cilegon (180) }\end{array}$ & $\begin{array}{l}\text { Jabar-Banten- } \\
\text { Jakarta (288) }\end{array}$ & 1,6 & OK \\
\hline & & $\begin{array}{l}\text { Yogya-Surakarta-Semarang } \\
\text { (16) }\end{array}$ & Bantul (6) & 0,375 & Surakarta-Semarang \\
\hline & & Jawa Timur (21) & Jember (1) & 0,05 & Surabaya \\
\hline \multirow[t]{4}{*}{3} & \multirow[t]{4}{*}{ Kalimantan } & Pontianak-Banjar Baru (32) & Pontianak (1) & 0,03 & Banjar Baru \\
\hline & & Palangkaraya (16) & - & $\sim$ & Palangkaraya \\
\hline & & Samarinda (5) & - & $\sim$ & Samarinda \\
\hline & & Bontang (1) & Bontang (1) & 1 & OK \\
\hline 4 & Sulawesi & Gowa (7) & Gowa (2) & 0,286 & Gowa \\
\hline
\end{tabular}

Sumber: Hasilpengolahan data peneliti (2017)

\section{c) Rangkuman Keseluruhan}

Hasil pengolahan data untuk F2, M1, M2 dan M3 dianalisis sebagaimana paparan kelas massa yang sebelumnya kemudian hasil akhirnya dirangkum dalam Tabel 7. Nampak dalam Tabel 7, standar massa E1 memiliki pemanfaatan yang paling baik, disusul berikutnya adalah standar E2 dengan nilai rasio pemanfaatan yaitu 0,9 , kemudian berikutnya adalah standar F1 dan M3, sedangkan standar F2, M1 dan M2 nampak memiliki rasio pemanfaatan yang lebih rendah. Ini menggambarkan bahwa kebutuhan konsumen untuk kalibrasi ketertelusuran standar massa signifikan lebih banyak berkaitan pada kelas massa utama yaitu E1 dan E2 karena kebanyakan Laboratorium kalibrasi dan industri mempunyai standar E2 yang digunakan sebagai kalibrator standar massa yang ada di bawahnya sehingga standar massa yang berada di bawahnya seperti F1, F2, M1, M2 dan M3 sebagian besar melakukan kalibrasi internal sendiri. 
Tabel 5 Rangkuman potensi pengembangan optimalisasi Laboratorium kalibrasi tersedia per standar massa di Indonesia.

\begin{tabular}{|c|c|c|c|c|}
\hline No & $\begin{array}{l}\text { Jumlah } \\
\text { Kelas } \\
\text { Standar } \\
\text { Massa }\end{array}$ & $\begin{array}{c}\text { Jumlah } \\
\text { Standar } \\
\text { Massa } \\
\text { (termanfaatkan) }\end{array}$ & $\begin{array}{l}\text { Rasio } \\
\text { Manfaat } \\
\text { Total }\end{array}$ & $\begin{array}{l}\text { Kota belum optimal } \\
\text { dimanfaatkan }\end{array}$ \\
\hline 1 & $E 1=112$ & $E 1=272$ & 2,4 & Pontianak \\
\hline 2 & $E 2=324$ & $E 2=302$ & 0,9 & $\begin{array}{l}\text { Pekanbaru, Samarinda, Palembang, } \\
\text { Palangkaraya, Banten, Cilegon, Yogyakarta, } \\
\text { Surakarta, Semarang, } \\
\text { Jatim }\end{array}$ \\
\hline 3 & $F 1=319$ & $F 1=246$ & 0,8 & $\begin{array}{l}\text { Palembang, Samarinda, Palangkaraya, } \\
\text { Gowa, Yogyakarta, Surakarta dan } \\
\text { Semarang }\end{array}$ \\
\hline 4 & $F 2=333$ & $\mathrm{~F} 2=83$ & 0,2 & $\begin{array}{l}\text { Padang, Palembang, Riau, MuaraEnim, } \\
\text { Pontianak, Samarinda, Bontang, Gowa, } \\
\text { Makassar, Surakarta dan Semarang }\end{array}$ \\
\hline 5 & $M 1=130$ & $\mathrm{M} 1=34$ & 0,3 & Jawa Barat, Surakarta dan Semarang \\
\hline 6 & $M 2=38$ & $\mathrm{M} 2=15$ & 0,4 & Batam, Semarang danJawaTimur \\
\hline 7 & $M 3=20$ & $M 3=15$ & 0,8 & Medan danSidoarjo \\
\hline
\end{tabular}

\section{d) Potensi Pengembangan Optimalisasi}

Secara umum hasil menunjukkan masih diperlukan optimalisasi pemanfaatan laboratorium kalibrasi yang terdapat di luar pulau Jawa, sehingga polarisasi pilihan laboratorium kalibrasi sebagai sumber ketertelusuran pengukuran di Indonesia dapat tersebar secara berimbang sehingga tidak berfokus pada Pulau Jawa semata.

Perimbangan ini menjadi hal yang sangat penting karena polarisasi menimbulkan efek biaya yang tidak sedikit. Prinsip perimbangan ini sangat penting karena perimbangan merupakan wujud dari upaya keadilan pemerataan. Ketika layanan kalibrasi ketertelusuran dapat dirasakan oleh klien diseluruh Indonesia secara merata maka hal ini akan memicu spiral interaksi kinerja tim di lingkungan internal LPK yang positif. Kinerja LPK yang positif akan menghasilkan proses bisnis penilaian kesesuaian yang sehat dan profesional (Breugst, 2015).

Pemerataan layanan kalibrasi sangat diperlukan dalam rangka optimalisasi potensi laboratorium kalibrasi yang ada. Pemerataan layanan kalibrasi bisa ditinjau dari 2 sisi yaitu pelayanan kalibrasi secara vertikal (kalibrasi ketertelusuran) dan pelayanan kalibrasi horizontal (kalibrasi dalam rangka sertifikasi pengujian, atau keperluan serupa). Ketidakmerataan yang terjadi di Indonesia adalah pada layanan kalibrasi secara vertikal. Distribusi pelayanan kalibrasi ketertelusuran standar massa terjadi polarisasi di pulau-pulau tertentu dan di daerah-daerah tertentu (Latarola, 2003), hal ini seiring dengan keberadaan pusat Laboratorium kalibrasi yang tidak merata di seluruh wilayah nusantara. Paling tidak pemerintah memiliki konsep yaitu untuk setiap pulau ada perwakilan laboratorium kalibrasi yang memang secara kebutuhan pasar telah dihitung untuk dapat melayani kebutuhan kalibrasi di wilayah pulau tersebut. Secara prinsip, pemerataan layanan dapat dilengkapi dengan pemerataan informasi melalui teknologi informasi yang dimiliki masyarakat. Diantara contohnya adalah klien atau masyarakat dimudahkan dalam mendapatkan informasi layanan kalibrasi melalui website dengan segala fitur-fitur kemudahan untuk mengakses informasi semua layanan laboratorium kalibrasi di Indonesia (Drajat, 2008).

Pemerataan layanan yang biasa disebut dengan distribusi keadilan, dapat juga diterapkan pada aspek harga layanan kalibrasi yang ditawarkan. Meskipun kondisi geografis dapat memunculkan masalah pemerataan layanan kalibrasi (Drajat, 2008), akan tetapi aspek harga bisa menjadi faktor pendorong penting dalam pemilihan layanan kalibrasi. Sebagai contoh, kita mengetahui bahwa harga layanan kalibrasi pemerintah lebih rendah dari laboratorium kalibrasi swasta dan sudah dipatok standar dan regulasi, sedangkan harga layanan kalibrasi swasta umumnya lebih kompetitif mengikuti permintaan percepatan waktu layanan. Pada Laboratorium kalibrasi milik pemerintah, meskipun memiliki harga yang relatif lebih rendah namun mayoritas terpolarisasi kalibrasi di Jawa maka praktis sama kondisinya yaitu membutuhkan biaya yang cukup besar (biaya transportasi) (Eichhorst, 2007).

Di Indonesia belum ada perwakilan SNSU di setiap Pulau, akibatnya meskipun terdapat laboratorium kalibrasi dengan: harga yang cukup, CMC terbaik dan profesionalitas 
tinggi maka tetap saja biaya tinggi, karena ongkos tranportasi pengiriman yang cukup besar. Salah satu kriteria keberhasilan pembangunan infrastruktur kalibrasi diantaranya ditandai dengan: 1) Mudahnya Laboratorium Kalibrasi daerah (di luar pulau Jawa) melakukan kalibrasi ketertelusuran (tidak jauh ke Jawa), 2) Pemerataan layanan ketertelusuran yaitu suatu keadaan yang sama mengenai ketersediaan standar untuk ketertelusuran kalibrasi baik di Jawa maupun di luar Jawa (Hakim, 2016). Pemerintah dalam hal ini BSN mempunyai peran untuk memberikan ketersediaan layanan kalibrasi lebih merata walaupun sebagian besar Laboratorium Kalibrasi memilih Laboratorium ketertelusurannya berdasarkan pertimbangan: kepercayaan terbaik, nilai CMC yang baik, biaya kalibrasi dan biaya transportasi (Hlayel, 2012).

Kualitas layanan kalibrasi pun harus selalu diperbaiki seiring dengan upaya pemerintah untuk meningkatkan pemerataan ketersediaan laboratorium kalibrasi di beberapa daerah. Karena selain penyediaan Laboratorium kalibrasi yang luas juga diperlukan pemenuhan sarana dan prasarana Laboratoriumkalibrasi yang konsisten disertai dengan penyediaan anggaran pemeliharaan dan peningkatan kapasitas kinerja SDM laboratorium kalibrasi (Lestari, 2013).

Berdasarkan hasil studi yang dilakukan oleh Maulana menyebutkan bahwa salah satu solusi dari belum maksimalnya pelayanan pemerintah bagi masyarakat secara luas adalah dengan melakukan "pemekaran" organisasi (Maulana, 2013). Ini artinya bahwa BSN dapat membuka sejumlah unit pelayanan teknis yang berada di daerah untuk meningkatkan perluasan layanan akreditasi laboratorium kalibrasi yang ujungnya berdampak pada peningkatan kemudahan laboratorium kalibrasi daerah untuk melaksanakan re-akreditasi.

Disisi lain, evaluasi pemerataan layanan kalibrasi dapat ditinjau dari sisi distribusi ekuitas imbalan yang diberikan (Melamed, 2012). Perbedaan yang terlalu besar antara harga kalibrasi di pusat dengan di daerah itu ada namun tidak berpengaruh signifikan terhadap perubahan perilaku pemilihan laboratorium kalibrasi penelusuran. Ada perbedaan antara swasta dan negeri namun kondisi itu seolah-olah sudah ada market tersendiri untuk itu. Dan dari sisi kualitas, keduanya hampir homogen. Di Indonesia adalah layanan kalibrasi yang lengkap peralatannya, kepercayaan tinggi dari tahun ke tahun, nilai CMC yang baik dan harga yang kompetitif sulit diperoleh terutama di luar pulau Jawa.

\section{KESIMPULAN}

Berdasarkan hasil pembahasan di atas maka dapat diambil kesimpulan bahwa secara umum polarisasi kepemilikan standar berfokus pada wilayah-wilayah di pulau Jawa sebanyak 990 standar massa, wilayah pulau Sumatera sebanyak 145 standar massa dan di Kalimantan sebanyak 157 standar massa dan di pulau Sulawesi tersedia 36 standar massa.

Ada wilayah/daerah rintisan yang berpotensi untuk pengembangan adalah daerah Nusa Tenggara Timur, Sulawesi Tengah, Sulawesi Tenggara, Sulawesi Utara, Maluku Utara, Maluku dan West Papua. Kesimpulan berikutnya, terdapat sejumlah kota yang memiliki laboratorium kalibrasi massa namun pemanfaatannya belum optimal yaitu wilayah Sumatera Barat, Kepulauan Riau, dan Sumatera Selatan untuk Pulau Sumatera, adapun di pulau Jawa yaitu kota Yogyakarta, sedangkan untuk Kalimantan yaitu wilayah Kalimantan Tengah dan untuk pulau Sulawesi maka di Sulawesi Selatan yang menjadi sorotan belum termanfaatkannya standar massa yang tersedia disana. Maka Pemerintah dapat memberikan fokus perbaikan promosi pemanfaatan layanan kalibrasi pada wilayahwilayah tersebut. Selanjutnya, dapat pula disimpulkan bahwa untuk standar massa E1 maka wilayah yang memiliki rasio manfaat $>1$ yaitu wilayah Jawa Barat-Banten-Jakarta, sedangkan kota yang perlu mendapatkan perhatian pemerintah terkait perbaikan pemanfaatannya adalah Medan, Surabaya, Yogyakarta dan Pontianak.

Standar massa E2 maka wilayah yang memiliki rasio manfaat $>1$ yaitu wilayah Jawa Barat-Banten-Jakarta dan Bontang, sedangkan kota yang perlu mendapatkan perhatian pemerintah terkait perbaikan pemanfaatannya adalah kota Medan, Pekanbaru, Palembang, Surakarta-Semarang, Surabaya, Banjar Baru, Palangkaraya, Samarinda dan Gowa.

Direkomendasikan bahwa pemerataan ketersediaan dan kemampuan laboratorium kalibrasi sebagai fungsi ketertelusuran kalibrasi di Indonesia belum tersebar dengan merata. Kepercayaan penuh masih dipegang statusnya pada sejumlah laboratorium kalibrasi di pulau Jawa. Penguatan ketersediaan Laboratorium kalibrasi dengan CMC yang baik, yang tersebar merata di setiap pulau-pulau besar dapat meningkatkan kepercayaan masyarakat terhadap kalibrasi ketertelusuran di Indonesia. Salah satu contohnya adalah BSN dapat membuka sejumlah unit pelayanan teknis 
SNSU yang berada di daerah untuk meningkatkan perluasan layanan akreditasi laboratorium kalibrasi yang ujungnya berdampak pada peningkatan kemudahan laboratorium kalibrasi daerah untuk melaksanakan re-akreditasi. Seiring dengan itu diperlukan juga peningkatan kualitas pelayanan informasi laboratorium ketertelusuran di Indonesia secara mudah dan jelas, sehingga sehingga klien dapat dengan mudah mencari mana laboratorium kalibrasi yang sesuai dengan kondisi standar massa yang dimiliki.

\section{UCAPAN TERIMA KASIH}

Penulis mengucapkan terima kasih yang sebesar-besarnya kepada pimpinan Badan Standardisasi Nasional (BSN) yang telah mengalokasikan anggaran untuk penelitian ini serta Bapak Ir. Juliantino, MM yang telah memberikan kesempatan untuk melaksanakan penelitian ini, juga terima kasih kepada Bapak Prof. Jimmy Pusaka dan Donny Purnomo atas ilmu dan waktu yang diberikan selama proses penulisan artikel ini. Juga tidak lupa penulis ucapkan terima kasih yang tiada terhingga Suprapto dan tim BSN atas waktu dan kesediaannya memberikan koreksi, saran dan masukan ilmu yang sangat bermanfaat sehingga artikel ini dapat tersusun dengan baik.

\section{DAFTAR PUSTAKA}

Badan Standardisasi Nasional. (2010). Sistem Standardisasi Nasional (SSN).

Retrieved Februari 11, 2019, from Download SSN: http://bsn.go.id/

Breugst, N. (2015). How should we divide the pie? Equity distribution and its impact on entrepreneurial teams. Journal of Business Venturing, Volume 30 , Issue 1, January 2015, Pages 66-94.

Drajat, M. S. (2008). Pelayanan Publik pada Sektor Komunikasi. Jurnal Meditaor, Vol.9, No.1, Juni.

Eichhorst, A. (2007). Evaluating the Need Assessment in Fiscal Equalization Schemes at the Local Government Level. The Journal of SocioEconomics, Volume 36, Issue 5, October 2007, Pages 745-770.
Hakim, L. (2016). Pemerataan Akses Pendidikan Bagi Rakyat Sesuai Dengan Amanat Undang-Undang Nomor 20 Tahun 2003 Tentang Sistem Pendidikan Nasional. Jurnal EduTech, Vol.2, No.1, Maret, 2016, Universitas Muhammadiyah Sumatera .

Hlayel, A. (2012). Solving Transportation Problems Using The Best Candidates Method. Computer Science \& Engineering: An International Journal (CSEIJ), Vol.2, No.5, October 2012.

KAN, K. A. (2016). Pedoman Evaluasi dan Pernyataan Ketidakpastian Pengukuran. Jakarta: Badan Standardisasi Nasional.

Latarola, P. (2003). Intradistrict equity dari sumber daya dan kinerja pendidikan publik. Economics of Education Review, Volume 22, Issue 1, February 2003, Pages 69-78.

Lestari, T. R. (2013). Pelayanan Kesehatan di Daerah Tertinggal, Perbatasan, dan Kepulauan. Info Singkat, Vol.V, No.12/II/P3DI/Juni/2013.

Maulana, S. (2013). Evaluasi Penyediaan Layanan Kesehatan di Daerah Pemekaran Dengan Metode CIPP (Studi pada Pemerintah Daerah Kabupaten Tana Tidung). Jurnal Wacana, Vol.16, No.4, 2013,

Melamed, D. (2012). Deriving equity from expectations: A cross-cultural evaluation. Social Science Research, Volume 41, Issue 1, January 2012, Pages 170-181.

Panteghini, M. (2009). Traceability as a unique tool to improve standardization in laboratory medicine. Clinical Biochemistry, Volume 42, Issues 4-5, March 2009, Pages 236-240.

Song, X. (2019). Virtual Calibration Quantitative Mass Spectrometry Imaging for Accurately Mapping Analytes Across Heterogenous Bio-tissue. Article in Analytical Chemistry · January 2019 with 14 Reads, 2-18.

Tistomo, A. S. (2014). Kemampuan Pengukuran dan Kalibrasi Suhu Dew/ Frost Point di Puslit Kim Lipi. Jurnal Standardisasi. 
Jurnal Standardisasi Volume 21 Nomor 2, Juli 2019: Hal 101 - 114

Jurnal Standardisasi Volume 21 Nomor 2, Juli 2019. Hal 101-114

